\title{
Perancangan Sistem Informasi Indeks Penyakit Rawat Inap Menggunakan Microsoft Visual Studio
}

\author{
Resti Adiyanti ${ }^{1}$, Putri Teja Sulaksana ${ }^{2,}$ Yuda Syahidin ${ }^{3}$, Meira Hidayati ${ }^{4}$ \\ ${ }^{1,2}$ Informatika Rekam Medis, Politeknik Piksi Ganesha Bandung, Indonesia
}

Info Artikel

Riwayat Artikel

Diterima: $14-06-2021$

Direvisi: 25-06-2021

Disetujui: 05-07-2021

Kata Kunci

Perancangan sistem; Indeks penyakit; Visual studio;

\section{Corresponding Author}

\section{Resti Adiyanti}

Politeknik Piksi Ganesha

Bandung

Tel.

piksi.resti.18403045@gmail.com

\begin{abstract}
ABSTRAK
Pengolahan data rekam medis pada saat ini tidak hanya dilakukan secara manual namun perkembangan teknologi saat ini juga mendukung kegiatan pengolahan data dilakukan menggunakan sistem berbasis komputerisasi. Pengolahan data secara manual, mempunyai banyak kelemahan, selain membutuhkan waktu yang lama, keakuratanya juga kurang dapat diterima, karena kemungkinan kesalahan sangat besar. Rekam medis memuat keterangan meliputi identitas pribadi, sosial, dan semua keterangan lain menyangkut pasien tersebut. Pengolahan data indeksing rekam medis di rumah sakit telah terintegrasi di SIMRS tetapi data indeks masih belum dapat di olah secara maksimal menjadi sebuah laporan, karena datanya masih belum terpisah antara data pasien rawat inap, rawat jalan, dan rawat darurat proses pengolahan indeks penyakit pasien rawat inap masih dilakukan secara semi-computerize. Hasil penelitian ini menyempurnakan aplikasi yang sudah ada menjadi sistem infromasi yang dapat mengolah data indeks penyakit pasien rawat inap dan menghasilkan laporan indeks penyakit dengan akurat.
\end{abstract}

\section{PENDAHULUAN}

Pengolahan data rekam medis pada saat ini tidak hanya dilakukan secara manual namun perkembangan teknologi saat ini juga mendukung kegiatan pengolahan data dilakukan menggunakan sistem berbasis komputerisasi. Pengolahan data secara manual, mempunyai banyak kelemahan, selain membutuhkan waktu yang lama, keakuratanya juga kurang dapat diterima, karena kemungkinan kesalahan sangat besar[1].Rekam medis memiliki tanggung jawab dalam proses mengolah data pasien mulai dari proses assemling, analisis, pemberian kode penyakit, hingga pembuatan indeks dan pelaporan rumah sakit. Karena teknologi berkembang pesat di bidang kesehatan maka beberapa kegiatan di rumah sakit sudah menggunakan sistem informasi. Sistem informasi memudahkan petugas rumah sakit dalam pengelolahan data seperti proses penginputan data, proses pengambilan data, pegupdatean data menjadi mudah, akurat, dan cepat.

Penggunaan sistem informasi di instansi rekam medis sangat membantu dalam mengelola data yang tercantum dalam kegiatam pelayanan kesehatan, meskipun belum semua kegiatan pengolahan data terintegrasi di SIMRS sehingga masih terdapat kelemahan yaitu dalam pengolahan data indeks penyakit, salah satunya indeks penyakit rawat inap.

Pengolahan data indeksing rekam medis di rumah sakit telah terintegrasi di SIMRS tetapi data indeks masih belum dapat di olah secara maksimal menjadi sebuah laporan, karena datanya masih belum terpisah antara data pasien rawat inap, rawat jalan, dan rawat 
darurat. proses pengolahan indeks penyakit pasien rawat inap masih dilakukan secara semicomputerize yaitu memasukan data secara manual ke dalam aplikasi Ms. Excel. Pengolahan data indeks penyakit melalui komputerisasi diharapkan membawa dampak baik di suatu instansi kesehatan. Dengan dirancangnya sistem ini diharapkan dapat membantu kegiatan indeksing.

1. Pengertian Perancangan

Perancangan adalah proses penerapan berbagai teknik dan prinsip yang bertujuan untuk mendefinisikan sebuah peralatan, satu proses atau satu sistem secara detail yang membolehkan dilakukan realisasi fisik[2]. Tujuan perancangan yaitu untuk memenuhi kebutuhan pemakaian sistem (user) dan memberikan gambaran yang jelas dan menghasilkan rancangan bangun yang lengkap kepada pemograman komputer dan ahliahli teknik lainnya yang terlibat dalam pengembangan atau pembuatan sistem.

2. Pengertian Sistem Informasi

Hampir seluruh aktivitas manusia sudah bergantung pada sistem informasi untuk berkomunikasi ataupun sekedar aktivitas sehari-hari. Sistem informasi adalah kumpulan elemen-elemen yang saling berinterkasi untuk mencapai sebuah tujuan. Sistem mengelola data sehingga menghasilhan informasi yang bermanfaat bagi manusia.

3. Pengertian Indeks Penyakit Rawat Inap

Indeks penyakit rawat inap adalah Indeks yang berisi tentang kasus- kasus penyakit pasien rawat inap mulai dari pasien masuk sampai kondisi akhir dari pasien saat pulang dari perawatan, indeks ini digunakan untuk pelaporan data morbiditas dan mortalitas yang digunakan sebagai pelaporan rumah sakit.

4. Pengertian Microsoft Visual Studio

Visual Basic adalah Program untuk membuat aplikasi berbasis Microsoft Windows secara cepat dan mudah. Visual Basic menyediakan tool untuk membuat aplikasi yang sederhana sampai aplikasi kompleks atau rumit baik untuk perus- ahaan/instansi dengan sistem yang lebih besar[3].

\section{METODE}

Penelitian ini menggunakan pengembangan metode waterfall dengan tahapan dimulai dari requirement (analisis kebutuhan), design system (desain sistem), coding (pengkodean) dan testing (pengujian), penerapan program, dan maintenance (pemeliharaan).

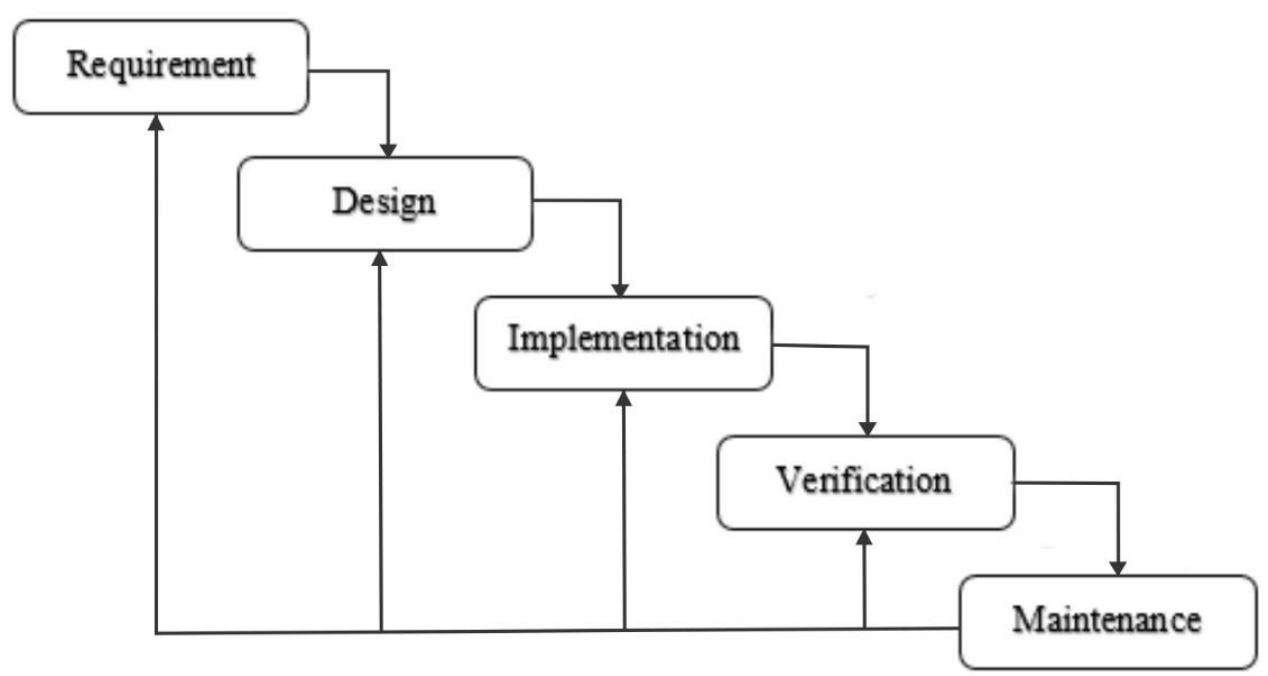

Gambar 1. Tahap metode Waterfall 1 
Analisis kebutuhan (requirement) informasi yang diperoleh melalui wawancara dan observasi kepada petugas indeksing dan petugas pelaporan mengenai kebutuhan perangkat lunak dan kebutuhan fitur pada sistem informasi yang akan dibuat.

Kebutuhan hardware dan software yang digunakan:

1. Spesifikasi Hardware

Perangkat keras yang digunakan:
a. Processor : Intel (R) Atom (TM) CPU N3060@2,48GHz
b. Memory :2.00GB
c. Harddisk : $8 G B$
d. Lain-lain : Keyboard, Mouse, Printer

2. Spesifikasi Software

a. Sistem Operasi : Windows 10

b. Bahasa Pemrograman : Microsoft Visual Studio 2010

c. Pengolahan Database : Microsoft Office Access 2007

d. Pengolahan Data : Microsoft Office Word

e. Pengolahan Laporan : Crystal Report

f. Rancangan Diagram : Microsoft Visio 2013

\section{Desain sistem}

Unutk mempermudah pembuatan perancangan sistem informasi indeks penyakit pasien rawat inap maka diperlukan Flowmap, Diagram Konteks, Data Flow Diagram (DFD) dan Entity Relationship Diagram (ERD) sebagai berikut:

\section{Flowmap yang Dirancang}

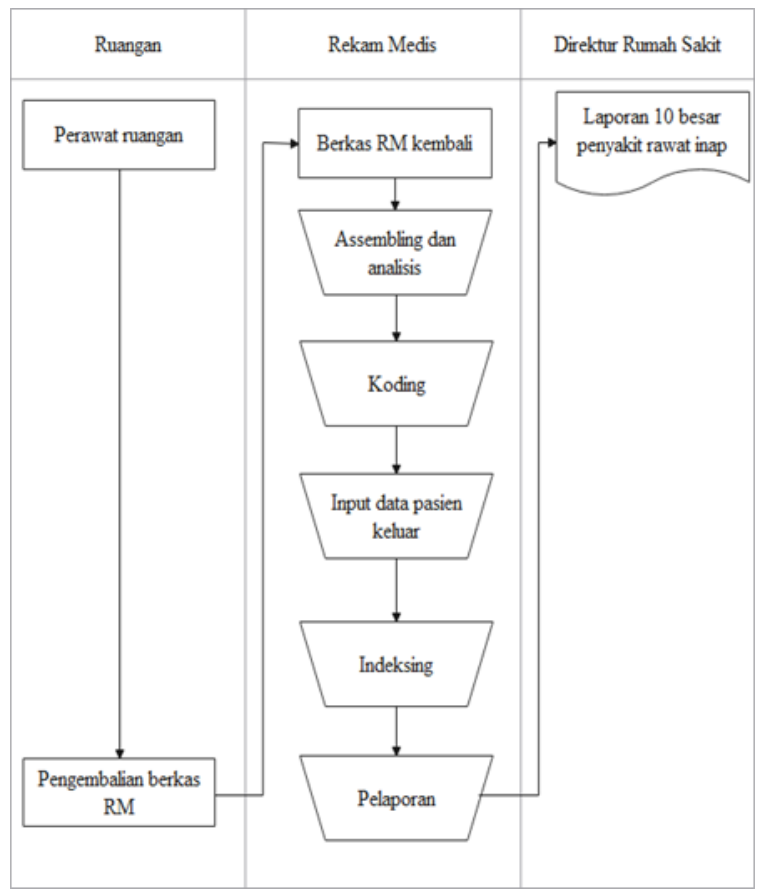

Gambar 2. Flowmap yang dirancang 


\section{Diagram Korteks yang Dirancang}

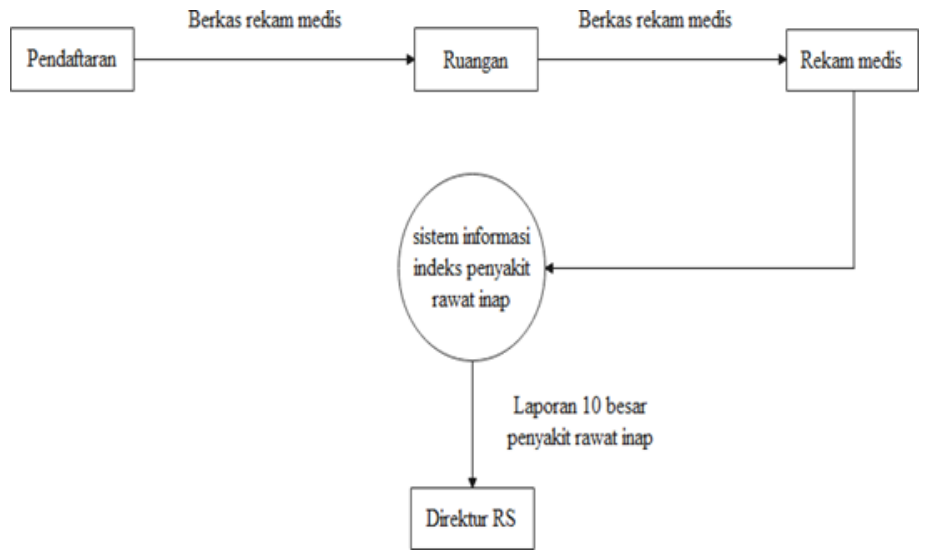

Gambar 3. Diagram Korteks Yang Dirancang

\section{DFD Level 0 yang Dirancang}

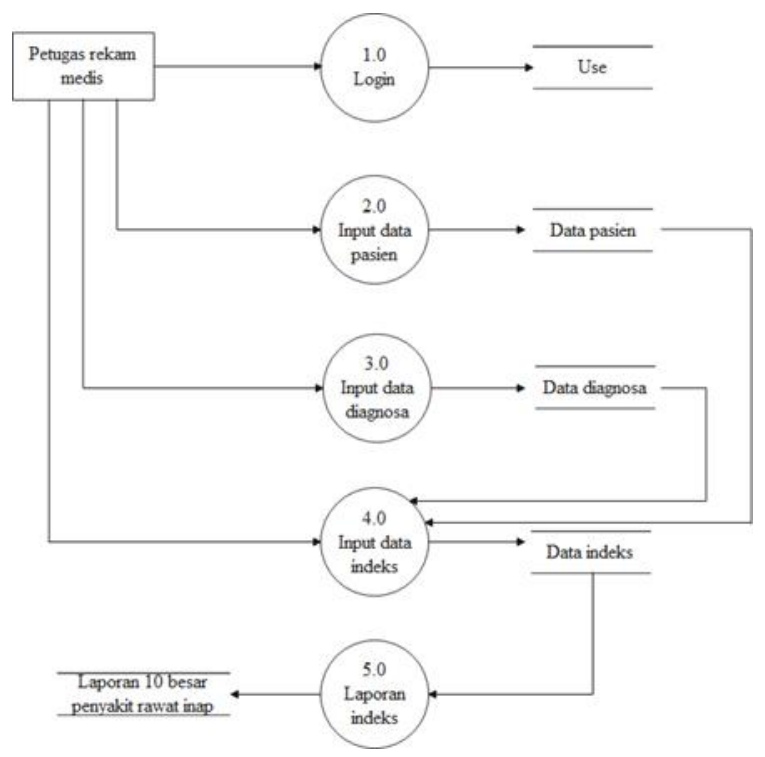

Gambar 4. DFD level 0 yang dirancang 


\section{Entity Relationship Diagram (ERD) yang Dirancang}

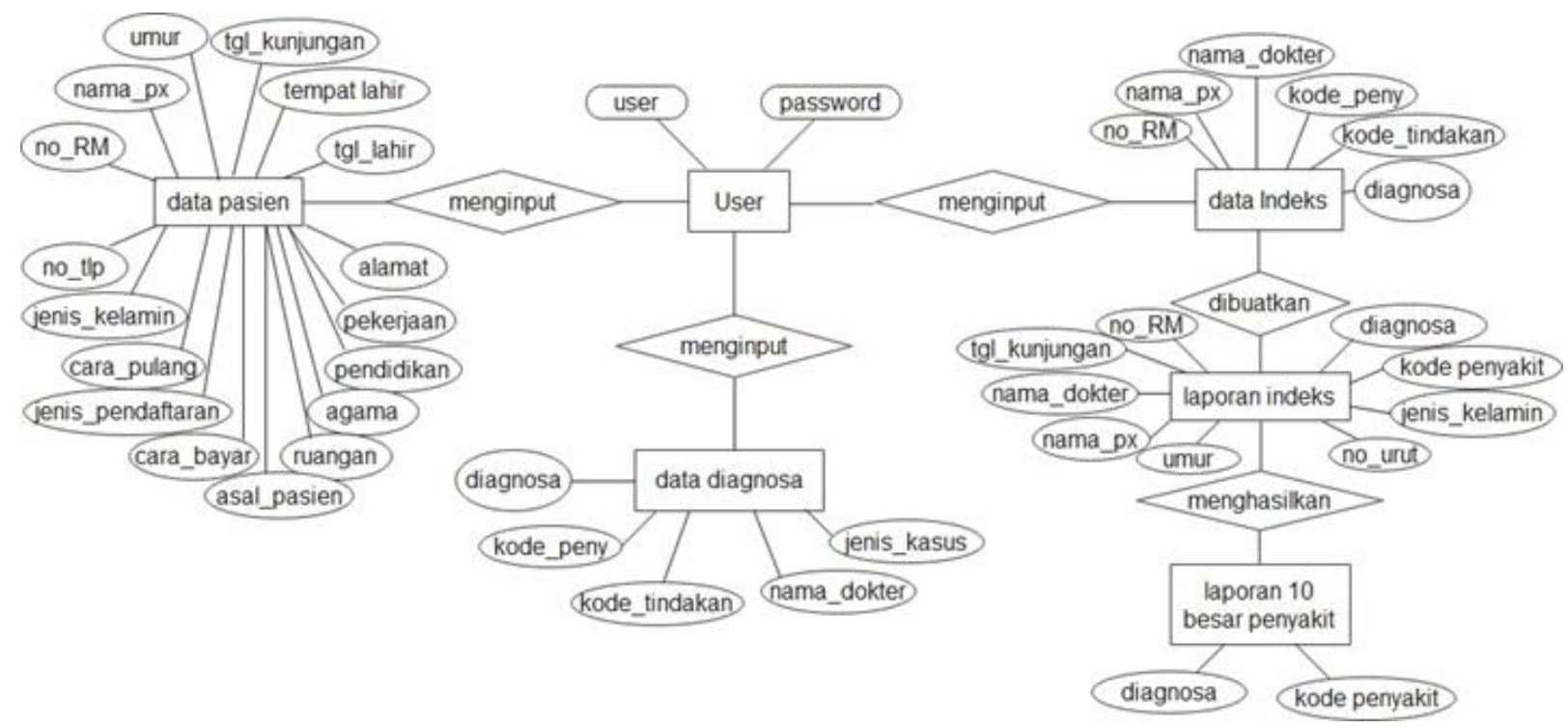

Gambar 5. ERD yang Dirancang

\section{HASIL DAN PEMBAHASAN}

\section{Interface Yang Dirancang}

Perancangan intrerface adalah tampilan aplikasi yang dibuat

\section{Form Login}

Tampilan untuk user melakukan login dengan memasukan username dan password

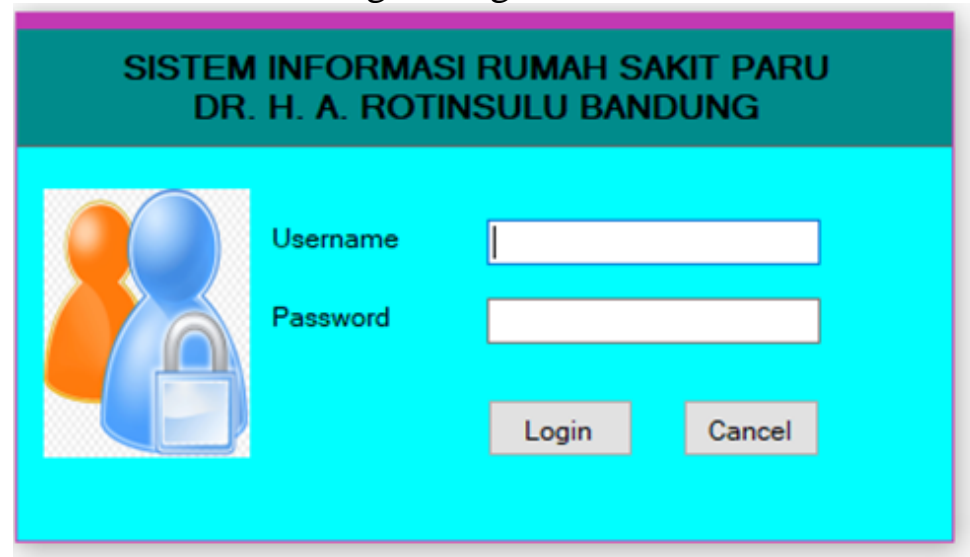

Gambar 6. Tampilan Form Login

\section{Form Halaman Utama}

Tampilan halaman utama setelah user melakukan login, dalam halam utama memuat form data pasien, data indeks, data diagnosa, dan laporan. 


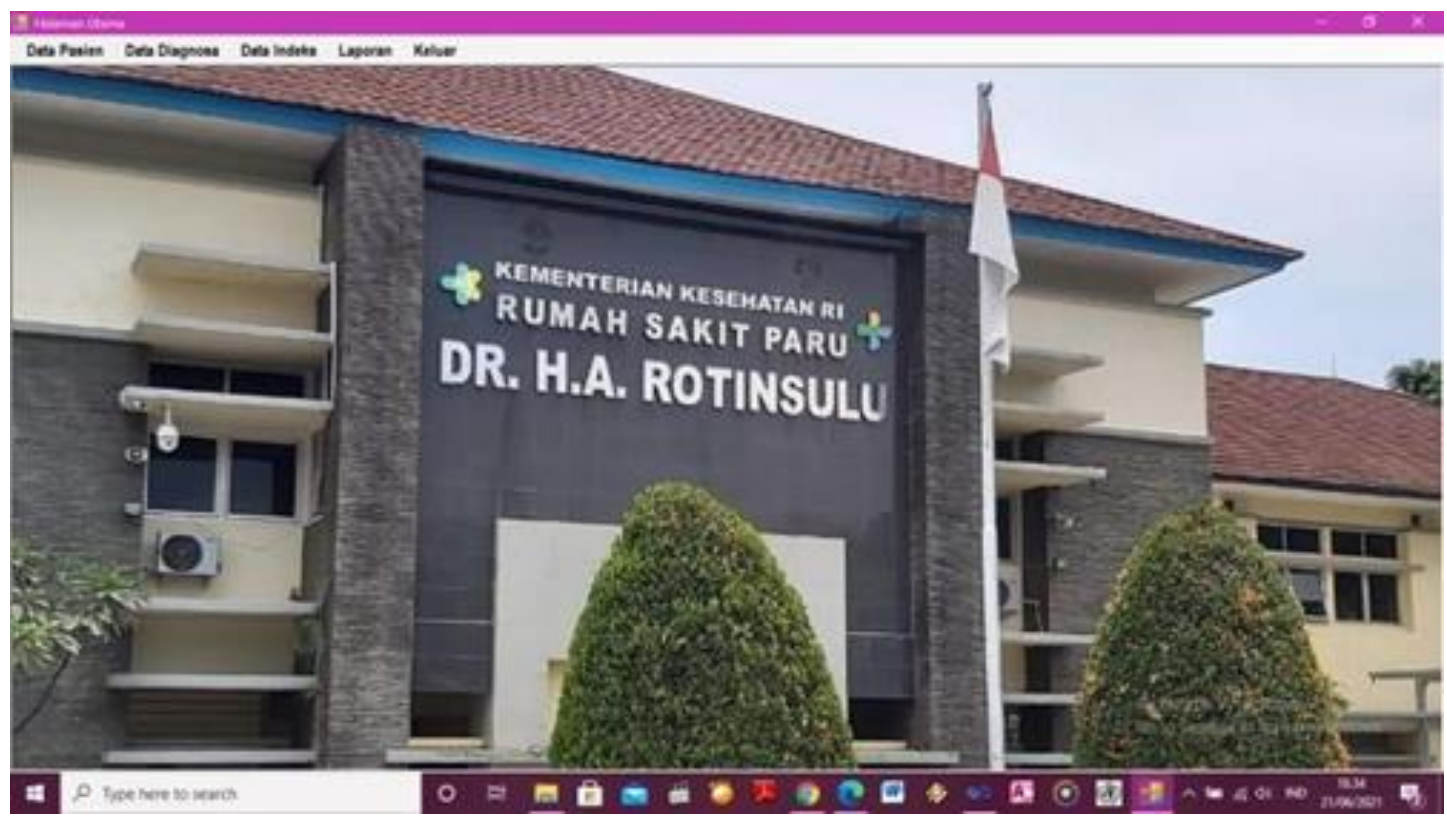

Gambar 7. Tampilan Form Halaman Utama

\section{Form Data Pasien}

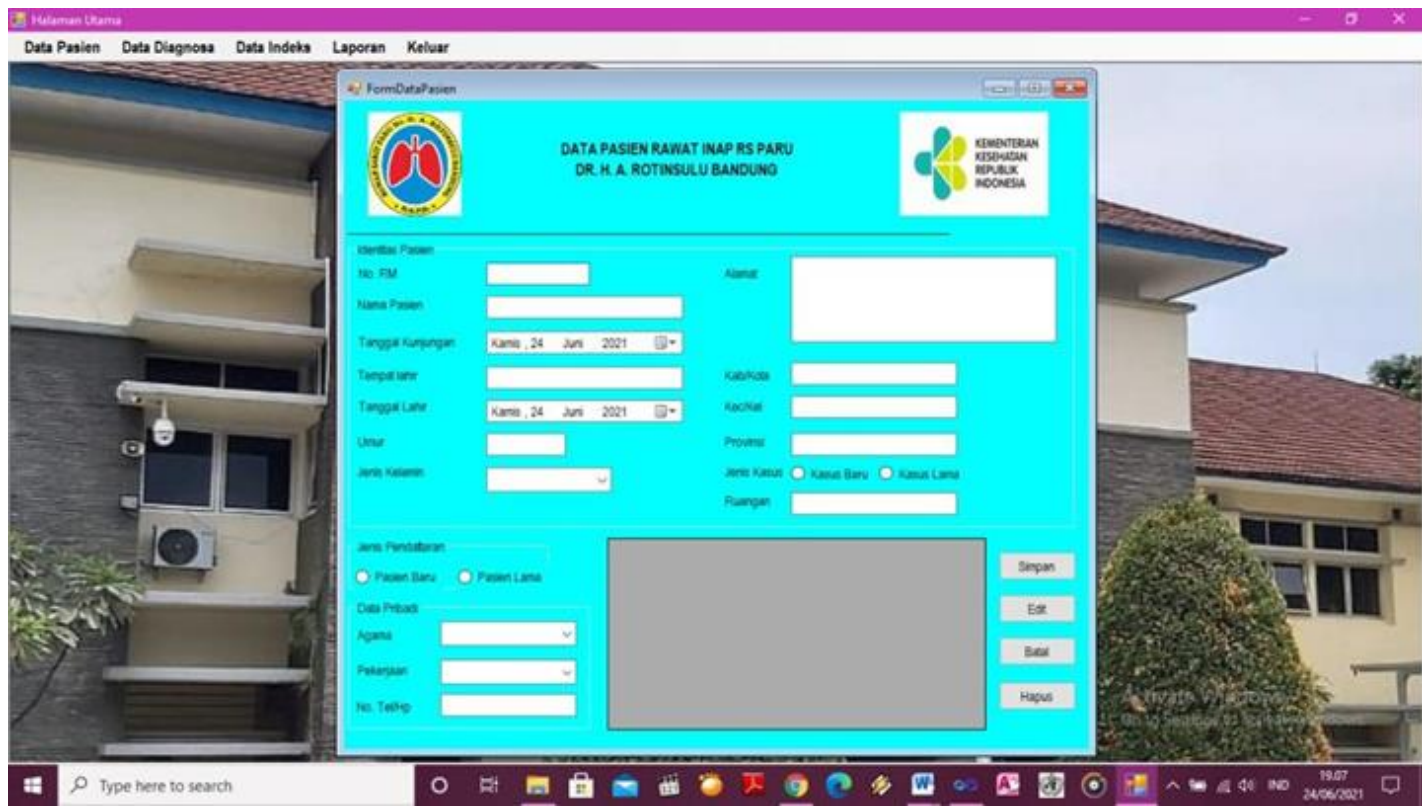

Gambar 8. Tampilan Form Data Pasien 


\section{Form Data Diagnosa}

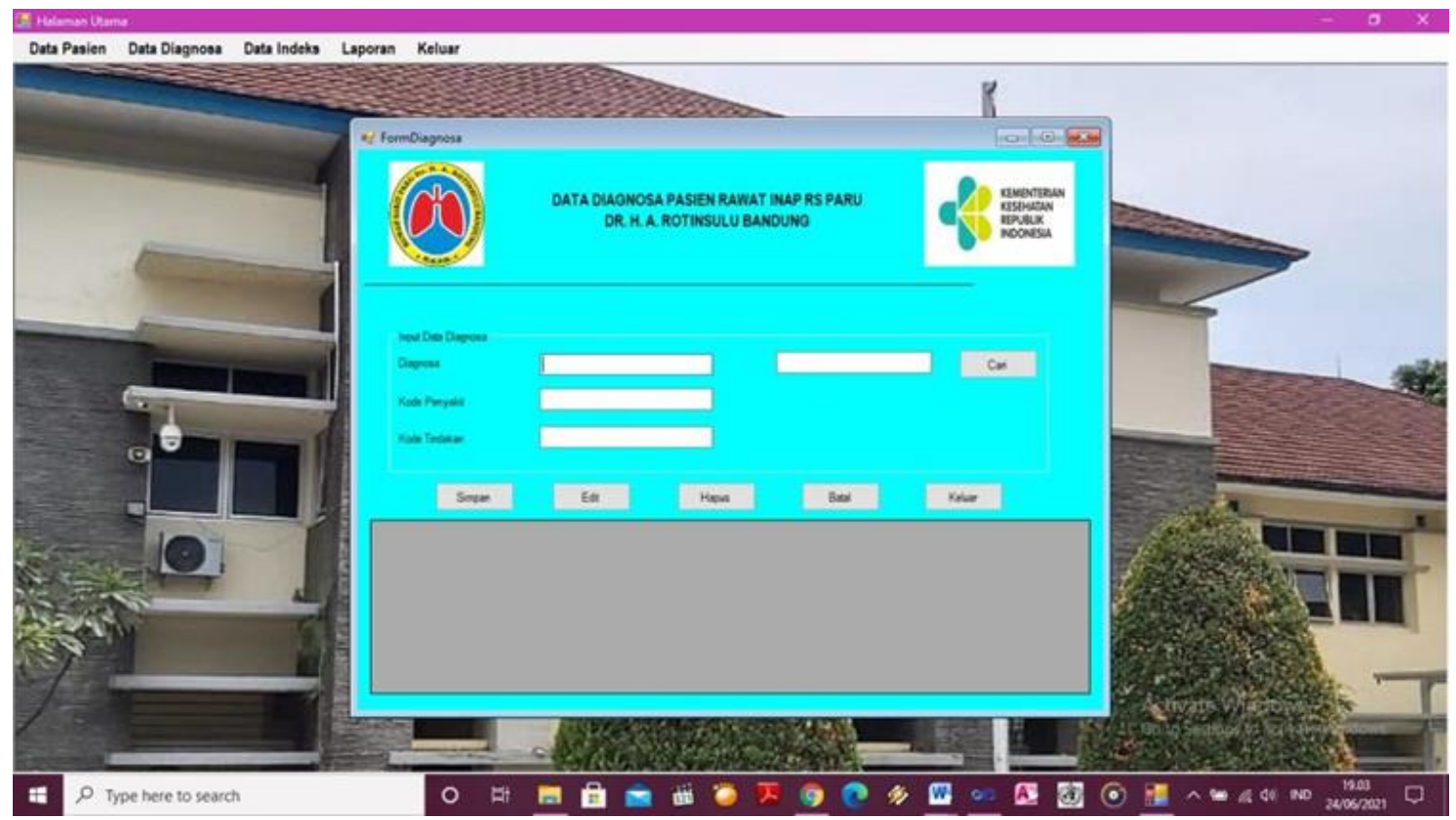

Gambar 9. Tampilan Form Data Diagnosa

\section{Form Data Indeks Penyakit}

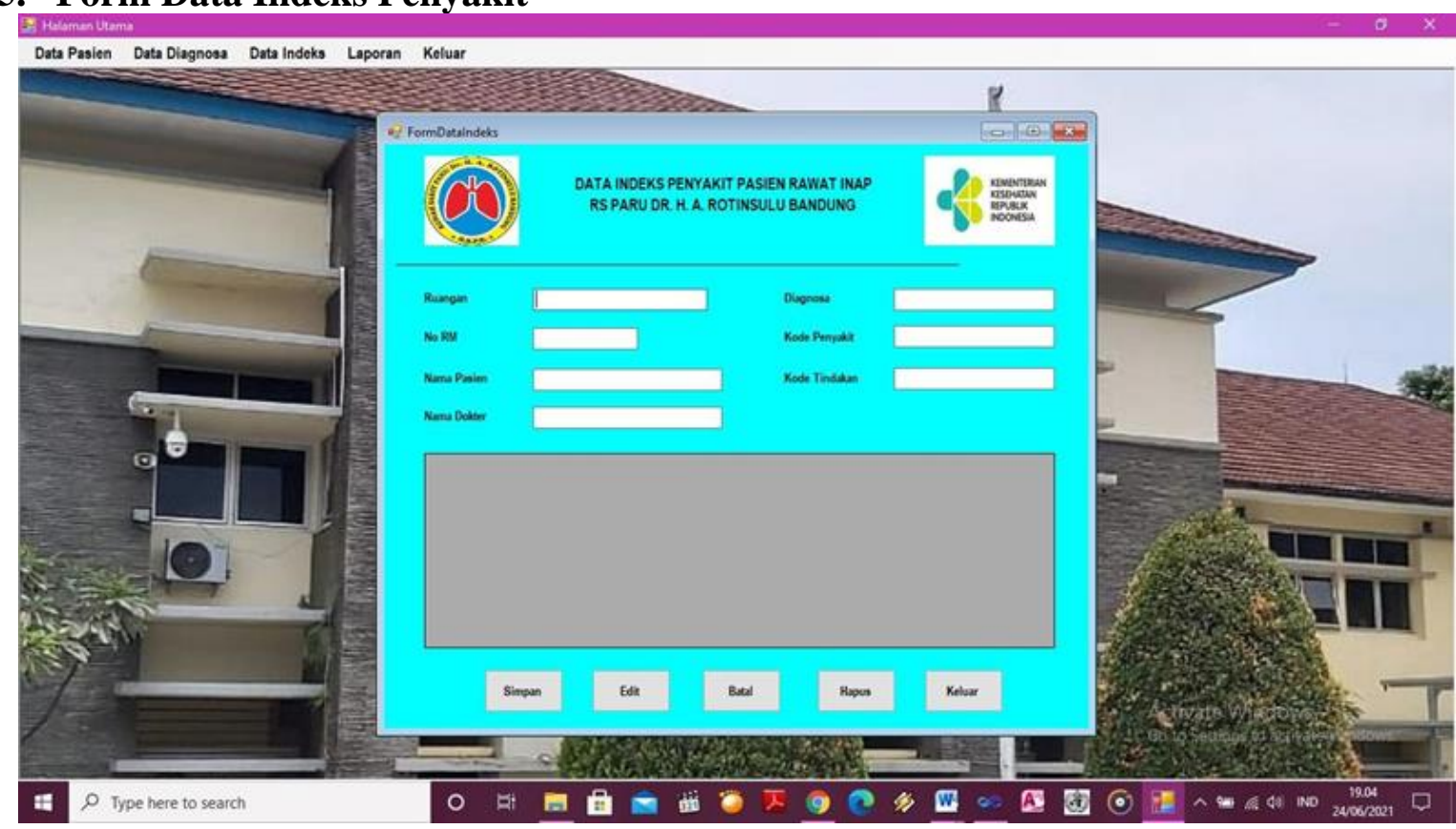

Gambar 10. Tampilan Form Data Indeks Penyakit 


\section{Form Laporan Indeks Penyakit Pasien Rawat Inap}

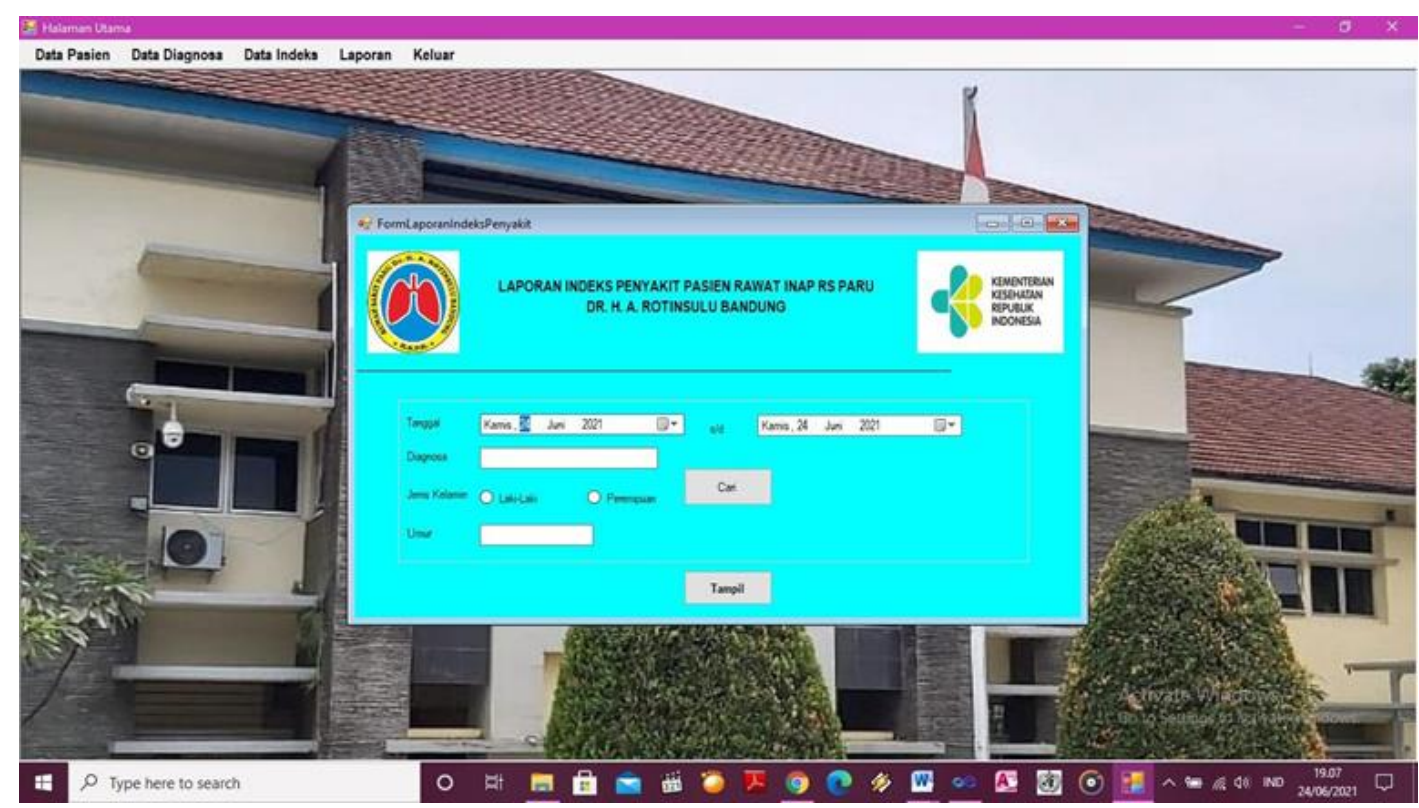

Gambar 11. Tampilan Form Data Indeks Penyakit

\section{Form Laporan 10 Besar Penyakit}

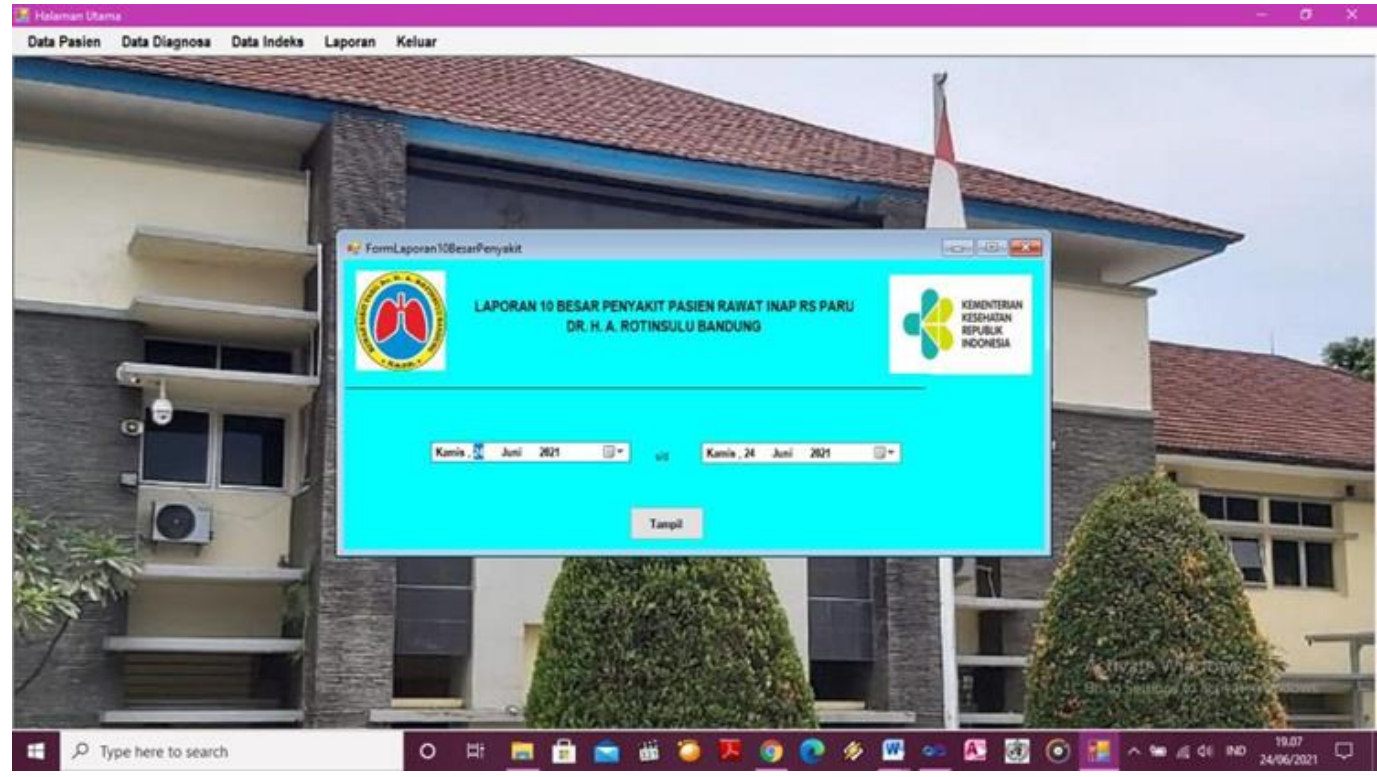

Gambar 12. Tampilan Form 10 Besar Penyakit 


\section{Tampilan Laporan Indeks Penyakit Pasien Rawat Inap}

\begin{tabular}{|c|c|c|c|c|c|c|c|c|c|}
\hline No & No RM & Nama & Tanggal & $\mathrm{JK}$ & Umur & Diagnosa & Kode & Dokter & Cara Keluar \\
\hline 1 & 103033 & MUHAMMAD GIFARI & 1/4/2021 & Laki-Laki & 22 & Respiratory Fallure & J96.9 & dr. Herudin & APD \\
\hline 2 & 111012 & JAJANG & $1 / 18 / 2021$ & Laki-Laki & 65 & CAP dengan Sepsis & A44. $.9+\mathrm{J} 17.0^{\circ}$ & dr. Herudin & APD \\
\hline 3 & 121312 & ELIS ROKAYAH & $1 / 4 / 2021$ & Wanita & 35 & Haemoptysis / Haemoptoe & R04.2 & dr. Sri & APD \\
\hline 4 & 124559 & ADE JUHANA & $1 / 12 / 2021$ & Laki-Laki & 50 & Tb. Paru BTA (+) & A 15.0 & dr. Herudin & APD \\
\hline 5 & 131321 & NINA AGUSTIN & $1 / 24 / 2021$ & Wanita & 19 & Pleural Effusion & J90 & dr. Herudin & APD \\
\hline 6 & 103214 & ATANG & $2 / 8 / 2021$ & Laki-Laki & 55 & Tumor Paru & 038.1 & dr. Sri & APD \\
\hline 7 & 112312 & NURAENI & $2 / 8 / 2021$ & Wanita & 23 & Tb. Paru Dengan & A 16.2 & dr. Herudin & APD \\
\hline 8 & 126785 & MUHAMMAD HUSNI & $2 / 15 / 2021$ & Laki-Laki & 29 & $\begin{array}{l}\text { Pemeriksaan Laboratorium } \\
\text { Tb. Paru BTA }(+)\end{array}$ & A 15.0 & dr. Herudin & APD \\
\hline 9 & 131345 & DENI FERNAWAN & $2 / 15 / 2021$ & Laki-Laki & 31 & MDR (Multi Drug Resisten) & A15.1 & dr. Herudin & APD \\
\hline 10 & 134545 & RIZKY FIRMANSYAH & $2 / 16 / 2021$ & Laki-Laki & 20 & $\begin{array}{l}\text { Tuberculosis } \\
\text { Hydropneumothoraks }\end{array}$ & J94/8 & dr. Sri & APD \\
\hline 11 & 131124 & RISMAYANTI & $2 / 16 / 2021$ & Wanita & 35 & Coronavirus infection, & uo7.1 & dr. Herudin & APD \\
\hline 12 & 131212 & RESTU SUCI & 2/16/2021 & Wanita & 22 & $\begin{array}{l}\text { Unspecified } \\
\text { Coronavirus infection, }\end{array}$ & uo7.1 & dr. Herudin & APD \\
\hline 13 & 121215 & IMAS & $2 / 17 / 2021$ & Wanita & 30 & $\begin{array}{l}\text { Unspecified } \\
\text { Adenocarcinoma Lung }\end{array}$ & C34.90 & dr. Sni & APD \\
\hline 14 & 112435 & ADE RAHMAT & $2 / 17 / 2021$ & Laki-Laki & 45 & Tumor Paru & D38.1 & dr. Herudin & APD \\
\hline 15 & 123535 & DEDI HIDAYAT & $2 / 18 / 2021$ & Laki-Laki & 32 & Tb. Panu BTA (+) & A 15.0 & dr. Sri & APD \\
\hline 16 & 131117 & NANIH & $2 / 18 / 2021$ & Wanita & 36 & Coronavirus infection, & U07.1 & dr. Sin & APD \\
\hline 17 & 124540 & IKA KARTIKA & $2 / 22 / 2021$ & Wanita & 29 & $\begin{array}{l}\text { Unspecified } \\
\text { Coronavirus infection, }\end{array}$ & U07.1 & dr. Herudin & APD \\
\hline 18 & 132320 & DANI & 2/22/2021 & Laki-Laki & 23 & $\begin{array}{l}\text { Unspecified } \\
\text { Tummor Paru }\end{array}$ & D38.1 & dr. Herudin & APD \\
\hline 19 & 112120 & YANI SURYANI & 2/23/2021 & Wanita & 34 & Tb. Paru BTA (+) & A 15.0 & dr. Sri & APD \\
\hline 20 & 131031 & NURHASANAH & $2 / 23 / 2021$ & Wanita & 20 & Tb. Paru BTA (*) & A 15.0 & dr. Herudin & APD \\
\hline
\end{tabular}

Gambar 13. Tampilan Laporan Indeks Penyakit

\section{Tampilan Laporan 10 Besar Penyakit}

\section{LAPORAN 10 BESAR PENYAKIT RAWAT}

\begin{tabular}{|l|l|l|}
\hline No & \multicolumn{1}{|c|}{ Diagnosa } & Kode \\
\hline 1 & Tb. Paru BTA (+) & A15.0 \\
2 & Tumor Paru & D38.1 \\
3 & Coronavirus infection, Unspecified & U07.1 \\
4 & Respiratory Failure & J96.9 \\
5 & CAP dengan Sepsis & A41.9+J17.0* \\
6 & Haemoptysis / Haemoptoe & R04.2 \\
7 & Pleural Effusion & J90 \\
8 & MDR (Multi Drug Resisten) Tuberculosis & A15.1 \\
9 & Adenocarcinoma Lung & C34.90 \\
10 & Hydropneumothorak & J94.8 \\
& & \\
\hline
\end{tabular}

Gambar 14. Tampilan Laporan 10 Besar Penyakit 


\section{SIMPULAN DAN SARAN}

Dari penelitian ini telah menghasilkan perancangan sistem informasi indeks penyakit pasien rawat inap dengan menggunakan microsoft visual studio, dengan menganalisa sistem yang telah berjalan dan dilakukan dengan cara wawancara secara langsung dan observasi, maka dapat disimpulkan bahwa:

1. Sistem ini layak digunakan di instansi rekam medis untuk proses indeksing. Sistem ini menampilkan form login, halama utama, data pasien, data indeks penyakit pasein rawat inap, laporan indeks penyakit berdasarkan diagnosa, tanggal kunjungan, jenis kelamin, dan usia.

2 Sistem ini juga dapat menampilkan laporan 10 besar penyakit pasien rawat inap berdasarkan periode tertentu.

\section{DAFTAR PUSTAKA}

[1] Handoyo, Aplikasi Sistem Informasi. 2008.

[2] B. Nadeak, A. Parulian, Pristiwanto, and S. R. Siregar, "Perancangan Aplikasi Pembelajaran Internet Dengan Menggunakan Metode Computer Based Instruction," JURIKOM (Jurnal Ris. Komputer), vol. 3, no. 4, 2016.

[3] A. Sunyoto, Pemrograman Database dengan Visual Basic dan Microsoft SQL 2000No Title. 2007.

[4] H. Jatnika, Sistem Informasi Manajemen Berbasis Komputer. Yogyakarta: ANDI, 2013.

[5] S. Mulyani, Sistem Informasi Manajemen Rumah Sakit:Analisis Dan Perancangan,From. 2016.

[6] Peraturan Menteri Kesehatan No. 269/MENKES/PER/III/2008 tentang Rekam Medis. 2008.

[7] D. R. D. Wijaya, Lily., "Manajemen Informasi Kesehatan II: Sistem Dan Sub Sistem Pelayanan RMIK.," 2017. 